\title{
Analysis of the First and Second Internal Transcribed Spacer Sequences of the Ribosomal DNA in Biomphalaria tenagophila Complex (Mollusca: Planorbidae)
}

\author{
Teofânia HDA Vidigal/* Linus Spatz**, Jessica C Kissinger***, Rodrigo AF Redondo****, \\ Edina CR Pires $* * * *$, Andrew JG Simpson $* * * * *$, Omar S Carvalho/ ${ }^{+}$
}

\begin{abstract}
Centro de Pesquisas René Rachou-Fiocruz, Av. Augusto de Lima, 1715, 30190-002 Belo Horizonte, MG, Brasil
*Laboratório de Malacologia e Sistemática Molecular, Departamento de Zoologia ****Laboratório de Biodiversidade e Evolução

Molecular, Departamento de Biologia Geral, Universidade Federal de Minas Gerais, Belo Horizonte, MG, Brasil

**Microbiología, Facultad de Medicina, Universidad de Buenos Aires, Buenos Aires, Argentina ***Center for Tropical and Emerging Global Diseases and Department of Genetics, University of Georgia, Athens, GA, US *****Laboratório de Genética do Câncer, Instituto Ludwig de Pesquisa sobre o Câncer, São Paulo, SP, Brasil ******Ludwig Institue for Cancer Research,
\end{abstract} New York, US

The first and second internal transcribed spacer regions (ITS1 and ITS2) of the ribosomal DNA of Biomphalaria tenagophila complex (B. tenagophila, B. occidentalis, and B. t. guaibensis) were sequenced and compared. The alignment lengths of these regions were about $655 \mathrm{bp}$ and $481 \mathrm{bp}$, respectively. Phylogenetic relationships among the Biomphalaria species were inferred by Maximum Parsimony and Neighbor-joining methods. The phylogenetic trees produced, in most of the cases, were in accordance with morphological systematics and other molecular data previously obtained by polymerase chain reaction and restriction fragment length polymorphism analysis. The present results provide support for the proposal that $\mathrm{B}$. tenagophila represents a complex comprising $\mathrm{B}$. tenagophila, B. occidentalis and B. t. guaibensis.

Key words: Biomphalaria - snails - ribosomal DNA - internal transcribed spacer - polymerase chain reaction

Freshwater snails of the genus Biomphalaria are widely distributed in Neotropical regions. The species $B$. glabrata, B. tenagophila, and B. straminea are intermediate hosts of Schistosoma mansoni, the ethiological agent of human intestinal schistosomiasis. Paraense (1984) described the subspecies B. tenagophila guaibensis as being indistinguishable from $B$. tenagophila by most of their genital characters. They are both very similar to $B$. occidentalis (Paraense 1981), but only B. tenagophila has been reported to be susceptible to $S$. mansoni infection (Paraense \& Corrêa 1987). B. t. guaibensis was described as a subspecies (Paraense 1984) due to the presence of a vaginal pouch (a qualitative character present in B. tenagophila). This character was considered to be more important than the size variation of the genital organs (a quantitative character similar to $B$. occidentalis). Paraense (1981) showed that B. t. tenagophila and B. occidentalis are separated by absolute reproductive isolation. However, no reports have been published about reproductive isolation, either between B.t. tenagophila and B. t. guaibensis or between B. t. guaibensis and B. occidentalis.

Biomphalaria internal transcribed spacers (ITS) ribosomal gene regions (including the 5.8S rDNA gene flanked by two ITS regions, ITS1 and ITS2) have been under study through analysis of sequence polymorphisms

Partial financial support: Fapemig and Pibic/Fiocruz ${ }^{+}$Corresponding author. Fax: + 55-31-3295.3115. E-mail: omar@cpqrr.fiocruz.br

Received 28 October 2003

Accepted 1 March 2004 using the polymerase chain reaction and restriction fragment length polymorphism (PCR-RFLP) technique. This methodology has been successfully used in molecular systematic and also genetic variability studies among morphologically similar species (Vidigal et al. 1998, 2001, Caldeira et al. 1998). In fact, Spatz et al. (1999), using PCRRFLP and morphological analysis, proposed to cluster $B$. tenagophila, B. occidentalis, and B. t. guaibensis into the $B$. tenagophila complex based on their genetic and morphological similarities.

The spacer regions, ITS1 and ITS2, of the rDNA gene are routinely used for studies on phylogenetic reconstruction, genetic variability and divergence of closely related species for a wide range of organisms (Subbotin et al. 2001, Weekers et al. 2001, Chilton et al. 2001, De Rojas et al. 2002), including molluscs and particularly within those groups with controversial taxonomy (Stothard et al. 1996, Remigio \& Blair 1997, Bargues et al. 2001).

In several studies, a close relationship between $B$. tenagophila and B. occidentalis has been also observed. In the genus Biomphalaria, nuclear ribosomal ITS1 and ITS2, partial 16S and cytochrome oxidase regions of mitochondrial DNA have been used as molecular markers for identification and phylogenetic analyses (Vidigal et al. 2000b, Campbell et al. 2000, DeJong et al. 2001). Most results from these studies are in accordance with classical systematics.

To further analyze molecular data on similar species from B. tenagophila complex, new sequences of the ITS1 and ITS2 regions of the ribosomal DNA were obtained from B. tenagophila and B. occidentalis, from Argentina, and B. t. guaibensis from Brazil and Uruguay (Table). 
These sequences were compared with others, previously obtained by Vidigal et al. (2000b) and De Jong (2001). The present study is aimed at estimating phylogenetic relationships within the B. tenagophila complex, using ITS1 and ITS2 sequences, in order to verify data about the convergence between molecular and morphological methods, previously obtained by Spatz et al. (1999).

\section{MATERIALS AND METHODS}

Snail populations and DNA extraction - Two or three specimens of B. tenagophila, B. t. guaibensis, and $B$. occidentalis were obtained from different localities of Brazil, Argentina, and Uruguay, in accordance with their geographical distribution in South America (Table). Most snail populations were collected in the field (Table). $B$. kuhniana and B. schrammi were used as outgroup. All of them were examined for the presence of $S$. mansoni cercariae by exposure to artificial light and they were found to be negative. Fixed snails were identified by means of comparative morphology based on the characteristics of reproductive organs and shells, according to Paraense (1975, 1981, 1984, 1988). Dr Lobato Paraense (Instituto Oswaldo Cruz-Fiocruz, Rio de Janeiro, Brazil) performed a confirmation of the morphological identification. Afterwards, total DNA was extracted from the feet of the snails using the Wizard Genomic DNA Purification Kit (Promega) with some modifications (Vidigal et al. 2000a). A reference snail for each DNA isolate has been preserved.

PCR amplification - The ITS1 region was amplified using the primers ETTS2 (5'-TAACAAGGTTT CCGTAGGTGAA-3') (Kane \& Rollinson 1994) and ITS1R (5'-ACGAGCGAGTGATCCACCGC-3') anchored in the $18 \mathrm{~S}$ and 5.8S regions of the rDNA, respectively. The ITS2 region was amplified using the forward $(\mathrm{F})$ primer ITS2F (5'-CGTCCGTCTGAGGGTCGGTTTGC-3') anchored in the 5.8 region (Vidigal et al. 2000) and the reverse (R) primer
ETTS1 (5'-TGCTTAAGTTCAGCGGGT-3') anchored in the $28 \mathrm{~S}$ region (Kane \& Rollinson 1994). The primer ITS1R was designed based upon analysis of 5.8 s sequences as described by Vidigal et al. (2000b). PCR conditions were the same as those mentioned by Vidigal et al. (2000b), except for the annealing temperature, which was $54^{\circ} \mathrm{C}$ for ITS1.

Sequencing - The ITS1 and ITS2 sequences of $B$. tenagophila, B. t. guaibensis, and B. occidentalis (Table) were obtained directly from the PCR products using the ABI PRISM BigDYE Terminator Cycle Sequencing Ready Reaction kit Protocol. PCR products were sequenced on an ABI Prism 377 DNA automated sequencer (PerkinElmer) as described by Vidigal et al. (2000b). ITS2 sequences from Brazilian snails, previously studied by Vidigal et al. (2000b), were included in the present study, as follows: B. tenagophila (3 sequences), B. occidentalis (2 sequences), $B$. kuhniana (1 sequence), and $B$. schrammi (2 sequences) (Table). Information on ITS1 and ITS2 sequences was also obtained from the GenBank (Table) for B. tenagophila species reported elsewhere (De Jong 2001) from Paraguay.

Alignment and phylogenetic analysis - For each (ITS1 and ITS2) region, a total of six sequences from $B$. tenagophila, three sequences from $B$. t. guaibensis, and four sequences from $B$. occidentalis were submitted to phylogenetic analysis as well as one more sequence from $B$. kuhniana and two sequences from B. schrammi specimens (Table). All ITS1 and ITS2 sequences were aligned with Clustal X (Thompson et al. 1997) and then refined by eye. All of phylogenetic reconstructions were performed using PAUP* Ver. 4.0b2a (Swofford 1999). Distance trees were constructed with the Neighbor-joining (NJ) algorithm, 10,000 bootstrap replicates, and the Kimura-2 parameter model. Parsimony (MP) reconstruction consisted of 500 random addition replicates and 1000 bootstrap replicates.

TABLE

Species, localities, abbreviations and GenBank access number of the ribosomal internal transcribed spacer 1 and 2 (ITS) of snail populations under study

\begin{tabular}{|c|c|c|c|}
\hline Species & Locality & Abbreviation & $\begin{array}{l}\text { GenBank access number } \\
\text { of ITS1/ITS2 }\end{array}$ \\
\hline Biomphalaria tenagophila & $\begin{array}{l}\text { Imbé, Rio Grande do Sul, Brazil }{ }^{a} \\
\text { Vespasiano, Minas Gerais, Brazil }^{a} \\
\text { Formosa, Goiás, Brazil }{ }^{a} \\
\text { Araza, Chaco Province, Argentina } \\
\text { Bonpland, Corrientes Province, Argentina } \\
\text { Paraguay }\end{array}$ & $\begin{array}{l}\text { BttRSBR } c \\
\text { BttMGBR } c \\
\text { BttGOBR } c \\
\text { BttChARG } \\
\text { BttCoARG } \\
\text { BttPAR } b\end{array}$ & $\begin{array}{l}\text { AY425730/AF198655 } \\
\text { AY425731/AF198654 } \\
\text { AY425732/AF198656 } \\
\text { AY425733/AY425746 } \\
\text { AY425734/AY425745 } \\
\text { AY030387 } b\end{array}$ \\
\hline B.t. guaibensis & $\begin{array}{l}\text { Esteio, Rio Grande do Sul, Brazil } \\
\text { Guaíba, Rio Grande do Sul, Brazil } \\
\text { Termas, Salto, Uruguay }\end{array}$ & $\begin{array}{l}\text { BtgRSBRA1 } \\
\text { BtgRSBRA2 } \\
\text { BtgSaURU }\end{array}$ & $\begin{array}{l}\text { AY425739/AY425749 } \\
\text { AY425740/AY425750 } \\
\text { AY425741/AY425751 }\end{array}$ \\
\hline B. occidentalis & $\begin{array}{l}\text { Capetinga, Minas Gerais, Brazil } \\
\text { Campo Grande, Mato Grosso do Sul, Brazil } \\
\text { Triângulo, Corrientes Province, Argentina } \\
\text { Villa Chica, Chaco Province, Argentina }\end{array}$ & $\begin{array}{l}\text { BocMGBR }^{c} \\
\text { BocMTBR }^{c} \\
\text { BoCOARG } \\
\text { BoChARG }\end{array}$ & $\begin{array}{l}\text { AY425737/AF198658 } \\
\text { AY425738/AF198657 } \\
\text { AY425735/AY425748 } \\
\text { AY425736/AY425747 }\end{array}$ \\
\hline B. kuhniana & Tucurui, Pará, Brazil & BkunPABR $^{c}$ & AY425742/ AF198666 \\
\hline B. schrammi & Ilicinea, Minas Gerais, Brazil & $\begin{array}{l}\text { BschMG1BR }{ }^{c} \\
\text { BschMG2BR }\end{array}$ & $\begin{array}{l}\text { AY425743/AF198681 } \\
\text { AY425744/ AF198682 }\end{array}$ \\
\hline
\end{tabular}

$a$ : laboratory populations; $b$ : sequences obtained from DeJong et al. (2000); $c$ : ITS2 sequences obtained from Vidigal et al. (2001b) 
Only bootstrap values higher than $70 \%$ were considered to be significant (Hillis \& Huelsenbeck 1992). Bootstrap values lower than $60 \%$ are not shown. For both analyses, trees were polarized by using $B$. schrammi, from Brazil, as the outgroup. B. schrammi is morphologically considered very distinct from the other species of the genus (Paraense 1975). In fact, previous phylogenetic studies showed that this species is very distant from other Brazilian Biomphalaria species (Vidigal et al. 2000b, DeJong et al. 2001). Additionally, one sequence from $B$. kuhniana was included in this analysis. According to morphological and phylogenetic analyses this species is very distant from other species that belong to the B. tenagophila complex (Paraense 1988, Vidigal et al. 2000b).

\section{RESULTS}

Characteristics of the ITS1 and ITS2 sequences - PCR amplification of ITS1 and ITS2 resulted in products of approximately 600 and 460 bp, respectively. Sequence lengths, within the $B$. tenagophila complex, range from 554 to $591 \mathrm{bp}$ for the ITS1 and from 399 to $413 \mathrm{bp}$ for the ITS2.

Phylogenetic analysis - ITS1 and ITS2 alignment lengths were 655 and 481 characters, respectively (data not shown). Unalignable regions were excluded from phylogenetic analysis. These included positions 636 to 655 of the ITS 1 alignment and positions 1 to 12 and 455 to 481 of the ITS2 alignment.

$B$. kuhniana is observed to be more closely related to the $B$. tenagophila complex than $B$. schrammi in all analyses (Figs 1,2). In all trees, B. kuhniana is on the base of $B$. tenagophila complex. Both methods, NJ and MP, generated similar trees when ITS1 sequences were analyzed (Fig. 1A, B). Parsimony analysis of ITS1 yielded 2277 equal parsimonious trees with a length of 204. Only the majority consensus tree is shown (Fig. 1B). Thus, both types of analysis support the monophyly of $B$. tenagophila species from Brazil (BttMGBR, BttRSBR, BttGOBR) and Paraguay (BttPAR), which cluster together with significant bootstrap support. The species from these localities are separated from B. tenagophila of Argentina (BttCOAR, BttCHAR), which are shown to be more closely related to B. occidentalis and B. t. guaibensis specimens (Fig. 1A, B). Due to the high degree of sequence conservation, the ITS1 sequence does not provide significant resolution within B. t. guaibensis and B. occidentalis groups and within the B. tenagophila from Argentina. However, it is interesting to note that there is significant support for a

\section{ITS1}

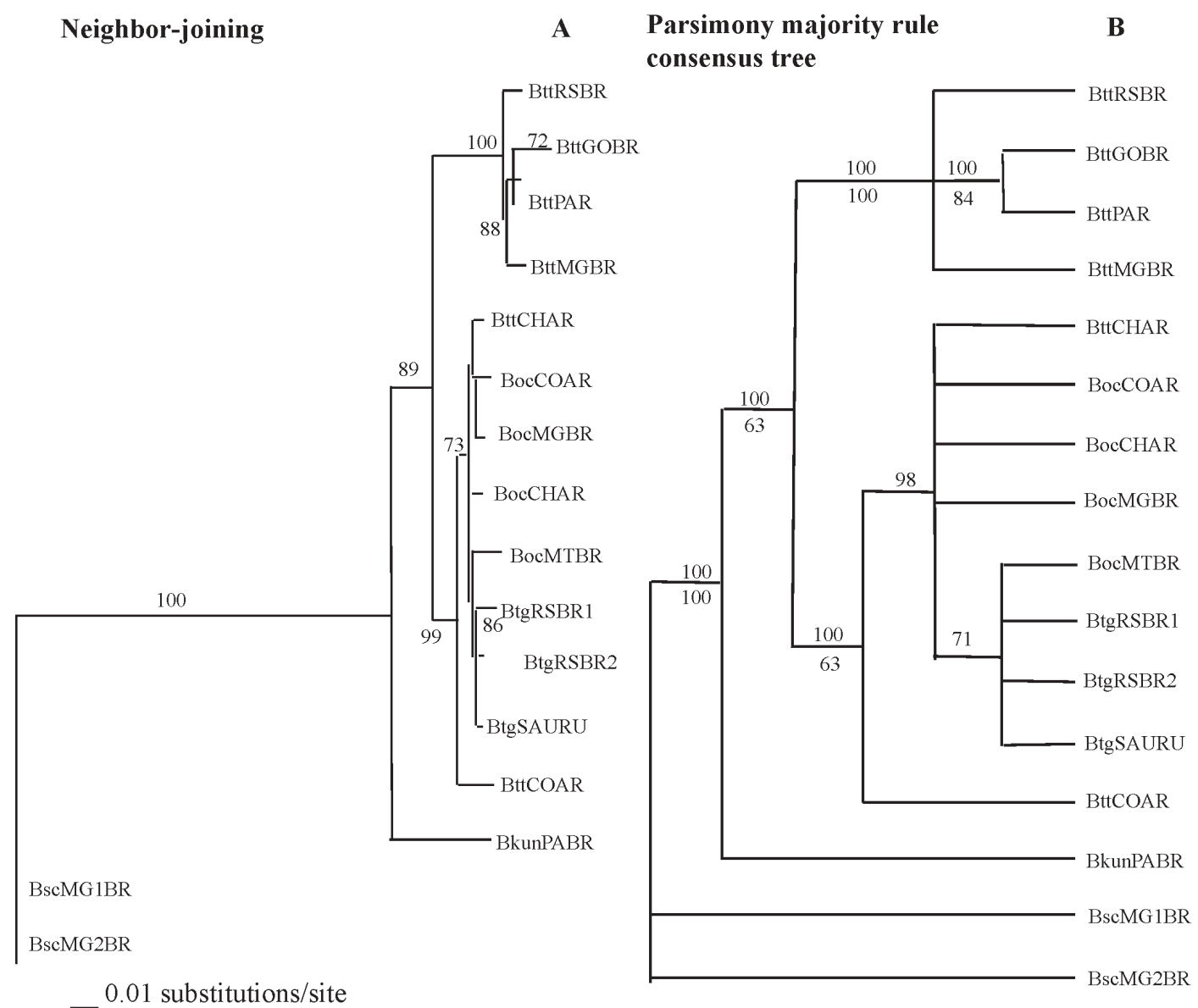

Fig. 1: trees resulting from phylogenetic analysis of ribosomal internal transcribed spacer 1 (ITS-1) sequences from individual snails belongs to Biomphalaria tenagophila complex (13 taxa). A: Neighbor-joining tree; B: Maximum parsimony tree (of 2277 most parsimonious trees). Sequences of two B. schrammi specimens and one B. kuhniana from Brazil (3 taxons) were considered as the outgroup. Bootstrap values lower than $60 \%$ are not shown. Species abbreviations are as defined in Table. 
subgroup within the $B$. ocidentalis, B. t. tenagophila consisting of $B$. ocidentalis from Mato Grosso Brazil (BocMTBR) and B. t. guaibenis from Rio Grande do Sul (BtgRSBR 1 and 2) Brazil and Uruguay (BtgSAURU) that is observed in both analysis.

Analyses of the ITS2 region generated trees with the same topology (Fig. 2A, B) using NJ and MP methods. Parsimony analysis yielded 2 equal parsimonious trees of length 96 one of which is shown in Fig. 2B. The trees shown in Fig. 2A and B present better resolution of branches with meaninful bootstrap values for $B$. $t$. guaibensis (90\% and 85\%) and B. occidentalis (100\% and 99\%) when compared with the ITS1 trees. However, these groups differ from the ITS1 trees with respect to the position of the B. occidentalis specimen, from Argentina (BocCOAR), which is shown to be more closely related to B. t. guaibensis, from Southern Brazil (BtgRSBRA1 and 2) and Uruguay (BtgSAURU), than with B. occidentalis. Like the ITS1 analysis, the ITS2 trees also show that $B$. tenagophila from Brazil (BttMGBR, BttRSBR, BttGOBR) and Paraguay (BttPAR) form a monophyletic cluster which is distinct from Argentinian B. tenagophila (BttCOAR, BttCHAR). Unlike ITS1 analysis, the ITS2 analyses group the $B$. tenagophila specimens from Argentina together with significant bootstrap values in both trees (Fig. 2A, B). This group is not clustered together with the group comprising B. t. guaibensis and B. occidentalis specimens. Another difference from the ITS1 analyses suggests that $B$. occidentalis and B. t. guaibensis show a closer relationship with $B$. tenagophila, from Brazil and Paraguay, than with B. tenagophila, from Argentina. Taken alone, this would suggest that the subspecies $B . t$. guaibensis has a stronger relation with $B$. occidentalis than with B. t. tenagophila.

\section{ITS2}

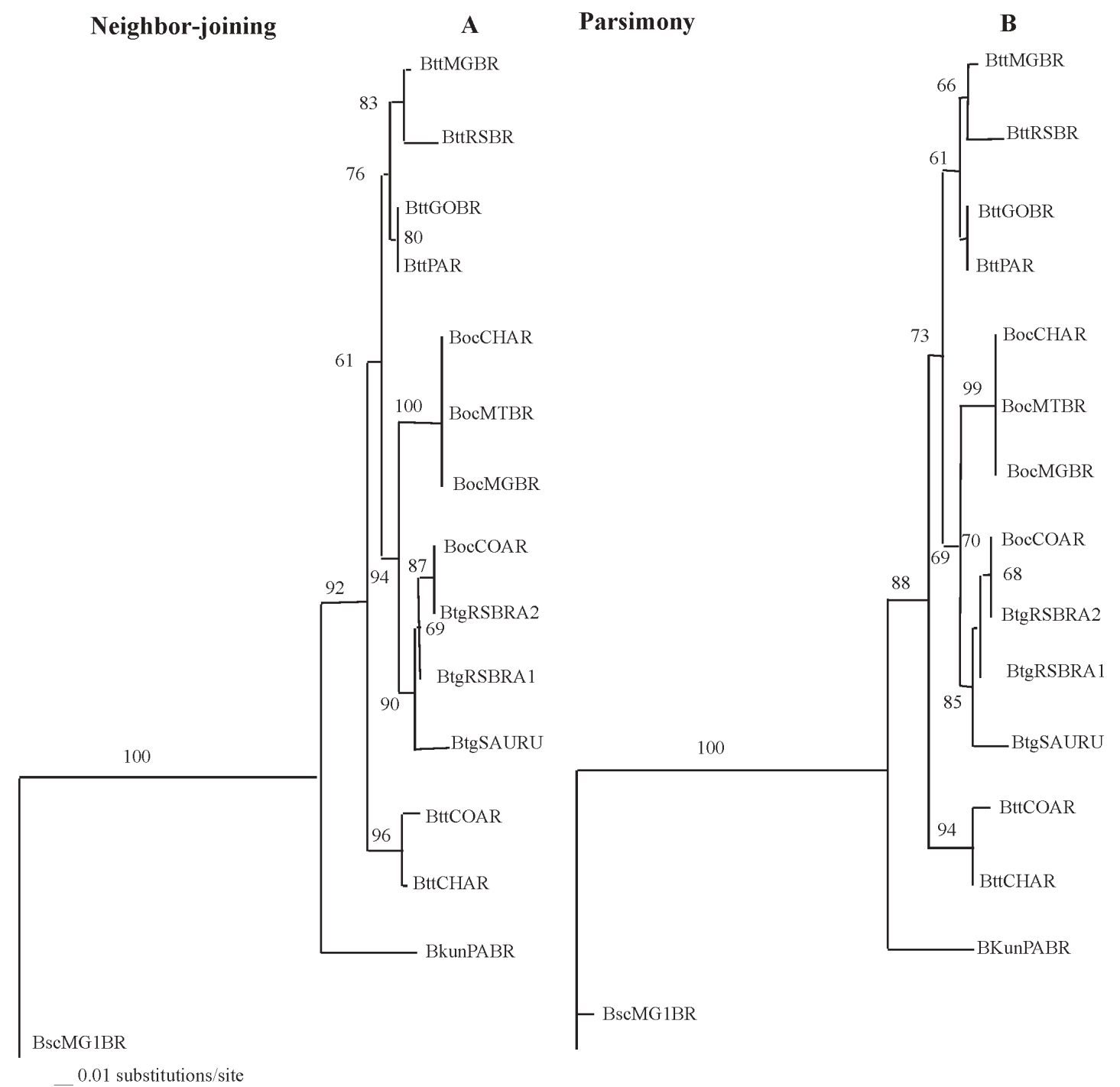

Fig. 2: trees resulting from phylogenetic analysis of ribosomal internal transcribe spacer 2 (ITS2) sequences from individual snails belongs to Biomphalaria tenagophila complex (13 taxa). A: Neighbor-joining tree; B: Maximum parsimony tree (only one of the two most parsimonious trees is shown). Sequences of two B. schrammi specimens and one B. kuhniana from Brazil were considered as the outgroup. Bootstrap values lower than $60 \%$ are not shown. Species abbreviations are as defined in Table. 


\section{DISCUSSION}

In previous studies, using different molecular techniques, we reported a high degree of intra-specific variability in several species of Biomphalaria from different Brazilian localities, as well as from Uruguay and Argentina (Vidigal e al. 1994, 1996, 1998, Pires et al. 1997, Caldeira et al. 2001, Campos et al. 2002). This variability is also observed when morphological characters such as vaginal pouch, vaginal wrinkling, penis sheath, prepuce, and prostatic diverticula are carefully analyzed (Paraense 1975, 1981, 1984, 1888).

The current report was designed to establish phylogenetic relationships among two species and one subspecies, which are very similar (B. tenagophila, B. occidentalis, and B. t. guaibensis), from Brazil, Argentina, and Uruguay using ITS1 and ITS2 sequence analysis. These specimens were previously submitted to morphological studies, genetic similarity analysis and PCR-RFLP specific identification, which grouped them in the $B$. tenagophila complex (Spatz et al. 1999).

Our results demonstrate that the ITS1 and ITS2 sequences, from B. tenagophila, B. t. guaibensis, and $B$. occidentalis species, have no substantial length differences. Stothard et al. (1996) reported a remarkable sequence divergence of ITS1 in Bulinus snails; however, conserved sequence has also been observed among some taxa. The length variation of Biomphalaria ITS1 sequences shown here (554-591 bp) is similar to that observed by Remigio and Blair (1997) for stagnicoline snails (541-586 bp) and greater than that observed for Bulinus (450-516 bp), according to Stothard et al. (1996). Here, the length variation in Biomphalaria ITS2 sequences (399-413 bp) are smaller than that produced by Remigio and Blair (1997) for stagnicoline snails (434-448 bp). Nevertheless, DeJong et al. (2001), studying American and African Biomphalaria molluscs, mentioned that ITS1 regions over such a diverse group had extreme length variation ranging from 548 to 778 nt. Regarding ITS2, these authors report a variation ranging from 403 to $509 \mathrm{nt}$. Although we have used a low number of species ( 2 species and 1 subspecies), a greater length variation for ITS1 (554-591) was also observed when compared with ITS2 (399-413). Other authors have already observed this fact concerning different organisms. For two species of the genus Dolichosaccus (Trematoda), Luton et al. (1992) reported a greater variation in ITS1 than in ITS2, whose findings also confirm that the ITS1 region may be aligned with some ambiguities whereas ITS2 is easily alignable. Thus, the region ITS2 has shown to be considerably valuable for parasite studies, while ITS1 is more widely used for closely related or sibling species as reported by Morgan and Blair (1995) in studies on the genus Echinostoma. These authors also remark that the ITS2 region may be useful for phylogenetic studies of distantly related species.

In our study, the trees obtained by ITS1 and ITS2 sequence analysis, revealed that $B$. kuhniana is more closely related to B. t. tenagophila than to B. schrammi. Such data is supported by molecular analysis, previously described (Vidigal et al. 2000b, DeJong et al. 2001). ITS1 sequence analysis, using MP and NJ methods, shows poor resolution among $B$. tenagophila snails from Argentina, B. occidentalis, and B. t. guaibensis and did not allow us to infer relationships among those species. This fact can be compared to PCR-RFLP data (Spatz et al. 1999) which also showed more similarity among $B$. tenagophila from Argentina, B. t. guaibensis, and B. occidentalis. On the other hand, the trees obtained by ITS2 analysis showed a close and clear relationship among $B$. tenagophila, from Brazil and Paraguay, with B. $t$. guaibensis and $B$. occidentalis. In contrast, $B$. tenagophila, from Brazil and Paraguay, are not closely related with B. tenagophila from Argentina based on molecular data.

Phylogenetic analysis of ITS2 sequences through both methods generated trees with similar topologies that were very concurrent with the morphological taxonomy proposed by Paraense $(1981,1984)$. Neither sequence nor previous PCR-RFLP studies grouped B. tenagophila from Brazil and Argentina together, although careful morphological identification has been performed and no differences could be observed between them. The poor resolution observed between B. t. guaibensis and B. occidentalis in ITS1 analysis and the fact that in both ITS2 trees the $B$. occidentalis from Argentina (BocCOAR) clusters with $B$. t. guaibensis, suggests that these organisms are related. To confidently state a likely relationship between $B$. tenagophila from Brazil and Argentina, as well as between B. t. guaibensis and B. occidentalis, further studies are needed.

In summary, considering: (1) Corrientes Province, Argentina is the type locality of B. tenagophila (Paraense \& Deslandes 1955, 1975); (2) morphological and molecular datas produced by Spatz et al. (1999), and (3) our results with ITS1 and ITS2 analysis, we suggest that specimens of B. tenagophila from different localities from South America be typed using molecular, morphological, and biological tools.

The data from DNA sequences will play an important role in the reconstruction of evolutionary relationships among these organisms and can also lead to new classifications, or confirm the traditional taxonomy.

\section{ACKNOWLEDGEMENTS}

To Dr Wladimir Lobato Paraense from Departamento de Malacologia, Instituto Oswaldo Cruz-Fiocruz, Rio de Janeiro, Brazil for assistance in morphological identification of Biomphalaria snails. To Langia Colli Montresor for providing valuable critical comments and Simone Silva for valuable administrative support.

\section{REFERENCES}

Bargues MD, Vigo M, Horak P, Dvorak J, Patzner RA, Pointter JP, Jackewicz M, Meier-Brook C, Mas-Coma S 2001. European Lymmnaeidae (Mollusca: Gastropoda), intermediate hosts of trematodiases, based on nuclear ribosomal DNA ITS-2 sequences. Infec Gen Evol 1: 85-107.

Caldeira RL, Vidigal THDA, Paulinelli ST, Simpson AJG, Carvalho OS 1998. Molecular identification of similar species of the genus Biomphalaria (Mollusca: Planorbidae) determined by a PCR-RFLP. Mem Inst Oswaldo Cruz 93: 219-225.

Caldeira RL, Vidigal THDA, Simpson AJG, Carvalho OS. 2001. Genetic variability in Brazilian populations of Biomphalaria 
straminea complex detected by simple sequence repeat anchored polymerase chain reaction amplification. Mem Inst Oswaldo Cruz 96: 293-302.

Campbell G, Jones CS, Lockyer AE, Hughes S, Brown D, Noble LR, Rollinson D 2000. Molecular evidence supports an African affinity of the Neotropical freshwater gastropod, Biomphalaria glabrata, Say 1818, an intermediate host for Schistosoma mansoni. Proc R Soc Lond B: 2351-2358.

Campos YR, Carvalho OS, Goveia CO, Romanha AJ 2002. Genetic variability of the main intermediate host of the Schistosoma mansoni in Brazil, Biomphalaria glabrata (Gastropoda: Planorbidae) assessed by SSR-PCR. Acta Trop 83: 19-27.

Chilton NB, Newton LA, Beveridge I, Gasser RB 2001. Evolutionary relationships of trichostrongyloid Nematodes (Strongylida) inferred from ribosomal DNA sequence data. Mol Phyl Evol 19: 367-386.

De Rojas M, Mora MD, Ubeda JM, Cutillas C, Navajas M, Guevara DC 2002. Phylogenetic relationships in rhinonyssid mites (Acari: Rhononyssidae) based on ribosomal DNA sequences: insights for the discrimation of closely related species. Parasitol Res 88: 675-681.

Dejong RJ, Morgan JA, Paraense WL, Pointier JP, Amarista M, Ayeh-Kumi PF, Babiker A, Barbosa CS, Bremond P, Pedro Canese A, De Souza CP, Dominguez C, File S, Gutierrez A, Incani RN, Kawano T, Kazibwe F, Kpikpi J, Lwambo NJ, Mimpfoundi R, Njiokou F, Noel Poda J, Sene M, Velasquez LE, Yong M, Adema CM, Hofkin BV, Mkoji GM, Loker ES 2001. Evolutionary relationships and biogeography of Biomphalaria (Gastropoda: Planorbidae) with implications regarding its role as host of the human bloodfluke, Schistosoma mansoni. Mol Biol Evol 18: 2225-39

Hillis DM, Huelsenbeck JP 1992. Signal, noise and reliability in molecular phylogenetics analyses. J Hered 83:189-195.

Kane RA, Rollinson D 1994. Repetive sequences in the ribosomal DNA internal transcribed spacer of Schistosoma haematobium, Schistosoma intercalatum and Schistosoma mattheei. Mol Biochem Parasitol 63: 153-156.

Luton K, Walker D, Blair D 1992. Comparisons of ribosomal internal transcribed spacer from two congeric species of flukes (Platyhelminthes: Trematoda: Digenea). Mol Biochem Parasitol 56: 323-328.

Morgan JA, Blair D 1995. Nuclear rDNA ITS sequence variation in the trematode genus Echinostoma: na aid to establishing relationships within the 37-collar-spine group. Parasitology 111: 609-615.

Paraense WL 1975. Estado atual da sistemática dos planorbídeos brasileiros. Arq Mus Nac Rio de Janeiro 55: 105-128.

Paraense WL 1981. Biomphalaria occidentalis sp.n. from South America (Mollusca Basommatophora Pulmonata). Mem Inst Oswaldo Cruz 76: 199-211.

Paraense WL 1984. Biomphalaria tenagophila guaibensis ssp. n. from Southern Brazil and Uruguay (Pulmonata: Planorbidae). I. Morphology. Mem Inst Oswaldo Cruz 79: 465469.

Paraense WL 1988. Biomphalaria kuhniana (Clessin, 1883), planorbid mollusc from South America. Mem Inst Oswaldo Cruz 83: 1-12.

Paraense WL, Corrêa LR 1987. Probable extension of schistosomiasis mansoni to southern most Brazil. Mem Inst Oswaldo Cruz 82: 577.

Paraense WL, Deslandes N 1955. Observations on the morphology of Australorbis nigricans. Mem Inst Oswaldo Cruz 53: 121-134.

Pires ER, Vidigal THDA, Teles HMS, Simpson AJG, Carvalho OS 1997. Specific identification of Biomphalaria tenagophila and Biomphalaria occidentalis populations by the Low Stringency Polymerase Chain Reaction. Mem Inst Oswaldo
Cruz 92: 101-106.

Remigio EA, Blair D 1997. Relationships among problematic North American stagnicoline snails (Pulmonata: Lymnaeidae) reinvestigated using nuclear ribosomal DNA internal transcribed spacer sequences. Can J Zool 75: 1540-1545.

Spatz L, Vidigal THDA, Caldeira RL, Dias Neto E, Cappa SMG, Carvalho OS 1999. Study of Biomphalaria tenagophila tenagophila, B. t. guaibensis and B. occidentalis by polymerase chain reaction amplification and restriction enzyme digestion of the ribosomal RNA intergenic spacer regions. J Molluscan Stud 65: 143-149

Stothard JR, Hughes S, Rollinson D 1996. Variation within the internal transcribed spacer (ITS) of ribossomal DNA genes of intermediate snail hosts within the genus Bulinus (Gastropoda: Planorbidae). Acta Trop 61: 19-29.

Subbotin AS, Vierstraete A, De Ley P, Rowe J, Waeyenberge L, Moens M, Vabfleteren JR 2001. Phylogenetic Relationship within the cyst-forming nematodes (Nematoda, Heteroderidae) based on analysis of sequences from the ITS regions of ribosomal DNA. Mol Phyl Evol 21: 1-16.

Swofford DL 2002. PAUP*: Phylogenetic Analysis Using Parsimony, (* and other methods). Version 4.0. Sinauer, Sunderland, Massuchusetts.

Thompson JD, Gilson TJ, Plewniak F Jeanmougin, Higgins DG 1997. The Clustal X windows interface: flexible strategies for multiple sequence alignment aided by quality analysis tools. Nucleic Acids Res 25: 4876-4882.

Vidigal THDA, Caldeira RL, Simpson AJG, Carvalho OS 2000a. Further studies on the molecular systematics of Biomphalaria snails from Brazil. Mem Inst Oswaldo Cruz 95: 57-66.

Vidigal THDA, Caldeira RL, Simpson AJG, Carvalho OS 2001. Identification of Biomphalaria havanensis and Biomphalaria obstructa populations from Cuba using polymerase chain reaction and restriction fragment length polymorphism of the ribosomal RNA intergenic spacer. Mem Inst Oswaldo Cruz, 96: 661-665.

Vidigal THDA, Dias Neto E, Carvalho OS, Simpson AJG 1994. Biomphalaria glabrata: extensive genetic variation in Brazilian isolates revealed by random amplified polymorphic DNA analysis. Exp Parasitol 79: 187-194.

Vidigal THDA, Dias Neto E, Simpson AJG, Carvalho OS 1996. A low stringency polymerase chain reaction approach to identification of Biomphalaria glabrata and Biomphalaria tenagophila intermediate snail hosts of Schistosoma mansoni in Brazil. Mem Inst Oswaldo Cruz. 91: 739-744.

Vidigal THDA, Kissinger J, Caldeira RL, Pires ER, Monteiro E, Simpson AJG, Carvalho OS 2000b. Phylogenetic relationships among Brazilian Biomphalaria species (Mollusca: Planorbidae) based upon analysis of ribosomal ITS2 sequences. Parasitology 121: 611-620.

Vidigal THDA, Motressor LC, Simpson AJG, Carvalho OS 2002. Polymerase chain reaction and restriction fragment length polymorphism of cytochrome oxidase I used for differentiation Brazilian Biomphalaria species intermediate host of Schistosoma mansoni. Mem Inst Oswaldo Cruz 97: 47-52.

Vidigal THDA, Spatz L, Nunes ND, Simpson AJG, Carvalho OS, Dias Neto E 1998. Biomphalaria spp: Identification of the intermediate snail hosts of Schistosoma mansoni by polymerase chain reaction amplification and restriction enzyme digestion of the ribosomal RNA gene intergenic spacer. Exp Parasitol 89:180-187.

Weekers PHH, De Jonckheere FJ, Dumont HJ 2001. Phylogentic relationships inferred from ribosomal ITS sequences and biogeographics patterns in representative of the genus Calopteryx (Insecta: Odonata) of the West Mediterranean and adjacent west European zone. Mol Phyl Evol 20: 89-99. 